\title{
Cálculo coraliforme masivo en la pielonefritis xantogranulomatosa crónica
}

\section{Massive coral calculus in chronic xanthogranulomatous pyelonephritis}

\section{CASE REPORT}

Xanthogranulomatous pyelonephritis (XPN) is a rare entity and constitutes less than $1 \%$ of chronic pyelonephritis. Symptoms are frequently nonspecific and in 2/3 of cases it is associated with renal stones (coral or Staghorn calculus) ${ }^{1}$.

A 66-years-old women presented with progressive asthenia, fever, night sweating and $7-\mathrm{Kg}$ weight loss over the last three months. Her medical history reported recurrent urinary infections, the last one a month before the symptoms began. On physical examination she presented with mucocutaneous pallor. Laboratory studies showed inflammatory anemia (hemoglobin $8.9 \mathrm{~g} / \mathrm{dL}$ ), leukocytosis, neutrophilia and $95 \mathrm{~mm} / \mathrm{h}$ erythrocyte sedimentation rate. The abdominal X-ray showed massive coral calculus overlying the left renal outline (Image 1), confirmed with abdominal CT, which also revealed a non-functioning left kidney and two pyelocaliceal purulent cysts. The clinic and radiological images were consistent with the diagnosis of chronic xanthogranulomatous pyelonephritis. Blood and urine cultures were negative. A percutaneous drainage CT guided was performed, isolating in microbiological cultures Proteus mirabilis. She completed a course of antibiotic followed by a left nephrectomy, with resolution of symptoms and anemia. Anatomopathological test was later performed and confirmed the diagnosis.

\section{REFERENCES}

1. Goyal S, Gupta M, Goyal R. Xanthogranulomatous pyelonephritis: A rare entity. N Am J Med Sci. 2011;3(5):249-250.

Palabras clave: pielonefritis xantogranulomatosa, cálculo coraliforme

Keywords: Xanthogranulomatous pyelonephritis, coral calculus

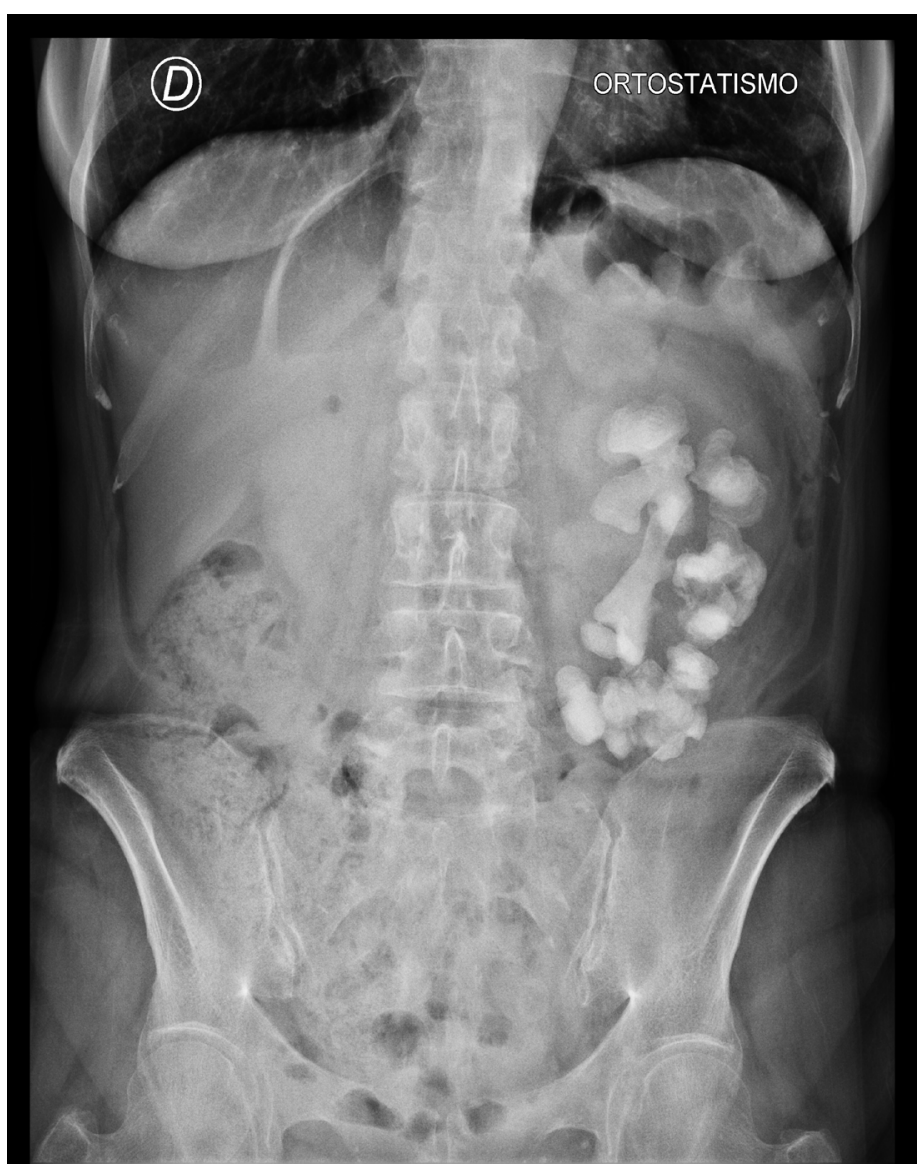

Sérgio Brito, Sérgio Pinho

Centro Hospitalar Lisboa Ocidental. Lisboa. Portugal

Correspondencia: sergioembrito@gmail.com

Cómo citar este artículo: Brito S, Pinho S

Cálculo coraliforme masivo en la pielonefritis xantogranulomatosa crónica. Galicia Clin 2021: 82-2: 119

Recibido: 28/2/2020; Aceptado: 20/1/2021 // https://doi.org/10.22546/61/2260 